\title{
FINDING BEST METHOD FOR CHILD PRISONER MEDIATION IN THE PROCESS OF TRANSITION BACK INTO COMMUNITY IN INDONESIA
}

\author{
Pan Lindawaty S. Sewu, Yohanes Hermanto Sirait, Ai Permanasari \\ Faculty of Law, Maranatha Christian University \\ E-mail: yohanessirait1988@gmail.com
}

\begin{abstract}
Children are the next generation of a state, no exception for child prisoner. There is limitless future for all children in the world, including Indonesia. The problem is, some of child prisoner transform into adult prisoner because their life background makes them hard to rejoin or accepted in any social community. This article aims to examine the best method for child prisoner mediation based on principle of for the best interest of the child. This article is a sociological juridical research, using secondary data and field data as addition. The data collected by using library research and analyzed qualitatively. This article finds that child prisoner mediation will help to provide opportunity for child prisoner and family members or other stakeholder to meet, with the help of a mediator, before release to have an open, honest, and sincere dialogue to prepare for the transition back into the community. The best interest of the child remains as core principle without decreasing other necessary principle in succussing mediation process. Child prisoner mediation is a process of mediation held especially for child prisoner and will restore the future of child prisoner in Indonesia.
\end{abstract}

Keywords: Child prisoner; Community; Mediation

\section{A. INTRODUCTION}

In the English language, there are orphans and widows, but there is no word for the parents who lose a child (Jodi Picoult, http://www.goodreads.com/quotes/tag/child). This is a good analogy to describe how important a child is, whatever the situation of the child. Child is the future of a state, accordingly a state should able to find any necessary ways to ensure that child future secured first.

The Convention on the right of the child defines a 'child' as a person below the age of 18, unless the laws of a particular country set the legal age for adulthood younger. The Committee on the Rights of the Child, the monitoring body for the Convention, has encouraged States to review the age of majority if it 
is set below 18 and to increase the level of protection for all children under 18 . The Convention applies to all children, whatever their race, religion or abilities; whatever they think or say, whatever type of family they come from. It does not matter where children live, what language they speak, what their parents do, whether they are boys or girls, what their culture is, whether they have a disability, whether they are rich or poor or whether they are a prisoner. No child should be treated unfairly on any basis or reason.

The best interests of children must be the primary concern in making decisions that may affect them. All adults should do what is best for children. When adults make decisions, they should think about how their decisions will affect children. This particularly applies to budget, policy and lawmakers.

This article, particularly highlight the situation of child prisoner. Their situation is not good because prison will never be a good place for them whatever the reason is. Prisons are too often places of conflict, violence, and fear (Laurel Kaufer, Douglas E. Noll, and Jessica Mayer, 2015: 14) and it may transform child worse as a person.

It is true that every crime has social costs, which can be harmful. In addition to the costs of law enforcement and investigating and prosecuting crimes, there are the costs of imprisonment, as well as the costs to the victims and the community. The social and economic costs of the offenders' failed reintegration are a major concern for policymakers around the world (M. Borzycki and T. Makkai, 2007: 133). Moreover, most of the child prisoner find it hard to return to their family and community because so little communication between them. The child his/herself unable to express their feeling because their fears of denial from others. Their family feels the same, they afraid that neighbourhood where they live will not accept their child and the worst their family refuse their return. Classic reason for the community, they do not want former prisoner will cause problem and affect other child.

Based upon the background above, this article will examine the possible method for child prisoner to transit back into community. The method rooted from one of alternative dispute resolution (ADR) called mediation. This child prisoner mediation (CPM) will be established on principle of the best interest of the child. This method is manifestation of child protection mandated by Convention on the Right of the Childs. Nevertheless, of course, this CPM is not sole way to do that. We can always use other method to complete it in order to achieve greater result.

\section{B. PROBLEM STATEMENT}

With accordance to background above, this article aims to find best method for child prisoner mediation in the process of transition back into community in Indonesia. 


\section{RESEARCH METHODS}

This research uses secondary data and field data as addition. Secondary data found in primarily from Constitution, Statutes and other regulation related to child right and ADR. The data also can be found from books, article, discussion paper that has relevance with this research. The field data obtained from Lembaga Pembinaan Khusus Anak (LPKA), a special custody for children in Bandung, Indonesia. The data collected by using library research and analyzed qualitatively (Kristina Simion, 2016).

\section{DISCUSSION AND RESEARCH RESULT}

\section{The Right of the Child Prisoner}

The child is unique human being with specific needs, and in relation to their age is categorize as a vulnerable group and thus requires special protection. As stated in the Declaration of the Rights of the Child:" ...the child , by reasons of his physical and mental immaturity needs special safeguards and care, including appropriate legal protection, before as well as after birth..." (Declaration of the Rights of the Child, proclaimed by General Assembly resolution 1386(XIV) of 20 November 1959). In the judicial process, the position of the child will be much more vulnerable than it has already been. Therefore, have to be ensured there is protection for the rights of the child according to the principles of child protection enshrined in human rights instruments. There are four principles that must always be applied in protecting the rights of the child: Non-discrimination principles; best interest of the child principle; principles of the right to life, survival, and development; and the principle of respect for the views of the child.

International law in the area of juvenile justice is substantial and detailed. The most important instruments for the administration of juvenile justice are the Convention of the Rights of the Child and the International Covenant on Civil and Political Rights. Apart from these international instruments, the United Nations standards and norms in crime prevention and criminal justice include four main instruments. All related to juvenile justice, the United Nations Standard Minimum Rules for the Administration of Juvenile Justice (the Beijing Rules), the United Nations Rules for the Protection of Juveniles Deprived of their Liberty, the United Nations Guidelines for the Prevention of Juvenile Delinquency (the Riyadh Guidelines) and the Guidelines for Action on Children in the Criminal Justice System (United Nation Office on Drugs and Crime, 2012). 
The policies of the Indonesian government in juvenile justice are in 1990 had ratified the Convention of the Rights of Child through Presidential Decree No. 36 and enacted through the Child protection Act No. 23 of 2002. Other regulations dealing with children in conflict with the law $(\mathrm{ABH})$ is Law Number 12 Year 1995 on Corrections, Legislation Number 3 Year 1997 on Juvenile Court, Law Number 39 Year 1999 on Human Rights, and The Law No.11 of 2012 on the Juvenile Criminal Justice System. The whole instruments relating to juvenile justice has the same norms of protection and fulfilment of the child rights, including the mandate to apply diversion and restorative justice in the law and in juvenile justice procedures.

The concept of restorative justice basically as defined in Article 1 SubArticle 6 of the Juvenile Justice System Law is the settlement of a criminal case involving perpetrators, victims, families of perpetrators / victims, and other parties concerned to jointly seek a fair settlement by emphasizing restoration to the original state, and not retaliation. Restorative justice is done to restore things to its original good by involving victims, perpetrators and communities in finding solutions that prioritize improvement and reconciliation. This is not only applied at the beginning of the criminal proceedings, but to restore it to the original state the process should reach the return of the perpetrator to the community where he was originally located. Reintegration of offenders into full membership of some community is among the aim of restorative justice (David Smith, 2005: 621-637).

The Convention on the Rights of the Child states clearly the purpose of the overall juvenile criminal justice system in international law of human rights is the reintegration of children and social reintegration. It is signed in clearly from article 40 (1) of the Convention on the Rights of the Child, which reads:

"States Parties recognize the right of every child alleged as, accused of, or recognized as having infringed the penal law to be treated in a manner consistent with the promotion of the child's sense of dignity and worth, which reinforces the child's respect for the human rights and fundamental freedoms of others and which takes into account the child's age and the desirability of promoting the child's reintegration and the child's assuming a constructive role in society. "

Social reintegration is often understood as the support given to offenders during their reintegration into society following imprisonment (C. T. Griffiths, Y. Dandurand and D. Murdoch , 2007). In the reintegration and rehabilitation program of the child prisoner, the cooperation from all parties is needed. The 
Beijing Rules stress the importance of the cooperation of the community in the rehabilitation of child offenders. They promote the mobilization of volunteers, local institutions and other community resources "to contribute effectively to the rehabilitation of the juvenile in a community setting and, as far as possible, within the family unit".

Released child offenders are often returning to families and communities that cannot accommodate them even under the best of circumstances. Therefore, supportive interventions during that period are particularly important. As part of an aftercare strategy from LPKA, a number of interventions can be delivered to assist child prisoner in reintegrating into their families and the community. The interventions must fit the needs and circumstances of the child, and the choice of an intervention should be based on a realistic assessment of the individual's challenges and needs.

Every year in Indonesia, some sentenced prisoners are released, some on parole and some on expiry of sentence. After finishing their prison sentences, it is society's expectation that they will refrain from committing crime and be productive citizens because they have been taught as normal law-abiding citizen in prison. They are expected to find employment, rebuild relationships with their families and communities, and cease from engaging in certain activities and avoiding the risks that caused their imprisonment in the first instance. Unfortunately, it is the case that many released prisoners commit further offences and find their way back to prison, some in a remarkably short period while others return after several years. In fact, some of them return after doing heavier crime than the previous one.

To support successful re-integration and to reduce recidivism, all child prisoners should benefit from arrangements designed to assist them in returning to society, family life, education or employment after release (United Nations Rules for the Protection of Juveniles Deprived of their Liberty, 1990). Therefore, procedures and special program should be devised to this end.

\section{Child Prisoner Mediation for The Transition Back Into Community}

Facilitating prisoner transit back to community is a difficult task and the impact of specific interventions is often difficult to measure (C. T. Griffiths, Y. Dandurand and D. Murdoch , 2007), especially for the child because they still depend so much to adult. There are many ways to do that, probation, parole or assimilation. Even in some case, sealing the criminal record of a prisoner who has desisted from crime and has completed a crime-free period in the community is a significant step in the social reintegration and an official acknowledgement of his 
or her success (R. Ruddell, L. T. Winfree, 2006). Child, of course need different treatment.

According to Article 40, paragraph 1, of the Convention on the Rights of the Child states that States parties should recognize "the desirability of promoting the child's reintegration and the child's assuming a constructive role in society". The Beijing Rules promote the importance of providing requisite facilities, methods and other necessary assistance as may further the best interests of the child. These principles will lead us to the awareness of the importance of a program that can facilitate prisoner's transition from detention to communities through the creation and maintenance of pro-social bonds and consequent informal social controls (Shawn M. Flower, 2013). A method that can be used as a reintegration tool, which is in the judicial system known as the peaceful method, is certainly a child-friendly method of mediation.

Mediation generally known as one of the alternative forms of dispute settlement which is an alternative for disputing parties to resolve their dispute by choosing a neutral third party (mediator) to lead the negotiations to assist the disputing parties to resolve their dispute amicably. Based on the definition of mediation, the authors argue that the elements of mediation, consisting of a) Dispute resolution is voluntary; b) intervention / assistance; c) assistance comes from impartial third parties; d) decision-making by the parties on a consensus basis; and e) the active participation of the parties to the dispute.

In Indonesia, mediation process for child implemented before the court process begin, usually called diversion. "Diversion, involving removal from criminal justice processing, and frequently redirection to community support services, is commonly practiced on a formal and informal basis in many legal system. This practice serves to hinder the negative effects of subsequent proceedings in juvenile justice administration (for example the stigma of conviction and sentence). Diversion is obligatory according to Article 5 (3) Law Number 11 of 2012. In case of prisoner release, in Indonesia, there is a program known as reintegration program as stated before.

It is certainty that at some point child prisoners will be released back into society. Therefore, it seems the sensible thing to provide prisoners with tools that will ensure when they are released, they can re-enter society, and the mediation while in prison will have just as many benefits for society as for the prisoner himself (Janus Conflict Management Service, http://boldmovestudio.com/janus/2012/03/09/prisoner-re-entry-mediation-better-than-cable-everytime/). Country like United State of America recognize a form of mediation called the re-entry mediation program. Re-entry mediation responds to the need for individuals returning from detention to have positive relationships 
with family and friends in the community. Through mediation, prisoner has a chance to mediate with family members before release, to address conflicts and collaboratively plan for the transition to the community (http://mdmediation.org/cmm-initiatives/re-entry-mediation ).

Child prisoner mediation opens opportunities for prisoners and others in raising their minds to solve existing problems between prisoner and families or communities. Preparing prisoner to return to the community and family, as well as preparing families and communities to re-accept the presence of the former prisoner. Mediation also provides an opportunity to design what a former prisoner will do upon returning to the community and family, in which case a former child prisoner may need further education, employment, or perhaps treatment for drug and alcohol abuse, it is indispensable so that former prisoners do not repeating the action contacting with the law anymore which will lead to go back to prison.

To make it all possible, it is important for the government to make efforts to place all prisoners close to their homes in order to facilitate ongoing contact between families and prisoners. Government also needs to ensure that prison policies and facilities allow for family visits to take place frequently and that contact (open) visits are used as a rule. As a general rule, not to place restrictions and censorship on letters and telephone communication, apart from individual high risk cases.

\section{Remission and Parole for Child based on The Result of Child Prisoner Mediation (CPM)}

Through Prisoner Child Mediation, child is able to reconnect and repair damaged relationships with family, friends, and society. By being able to reconcile relationships with people important in their lives, child is less likely to fall back into the same mistake that brought them into prison in the first place. In short, this method can help child to rebuild their future and reach their goals in life. As addition, mediation may also facilitate them to get their right as prisoner. The result of mediation can help government to determine whether the child given remission or parole. It can complete the requirement for remission and parole or fill it as progressive step to accelerate the development of child prisoner.

Remission is the reduction in the length of a prisoner's or child prisoner's sentence that fulfils the requirement according to prevailed law. It is their right according to Article 34 (1) of Government. Generally, prisoner earned remission if they behave well in prison and undergo sentence more than 6 (six) months. However, the problem is, their good behaviour mostly measured according to what they do in prison while the most important is what they will do in their environment after released. Hence, mediation program for child in their 
next environment is important and become appropriate as legal basis to earn remission because the result of mediation is the idea from the child and others who will he/she live with.

The basic philosophy of parole is that a prisoner shall not be held any longer than necessary, as it is detrimental to his or her reformation and an unnecessary expense to the State. According to Article $12(\mathrm{k})$, parole may be given after the prisoner (child) undergo 2/3 (two-third) of his/her sentence under the condition that the sentence is not less than 9 (nine) months.

There are some requirement needs to be fulfilled by the child for getting parole. According to Article 6 Regulation of Ministry of Law and Human Right Number 1 of 2007, there are substantive and administrative requirement. Substantively, community can accept developing program for prisoner (child) and the child him/herself and administratively, family of the child must prepare a statement letter of capability from family, school, government or private institution admitted by at least headman where the child will live. This requirement is easy to said but hard to get because not every community compliant with it. Essentially, the relationship of child prisoner with his/her family, friends and community damaged because of their action. Therefore, it is hard for others to accept them back as part of their life. It becomes harder if the crime are killing and rape. Most of people hardly to believe that the child may repent. Therefore, prisoner child mediation becomes substantial to realize it.

A mediator in PCM help child to express their feeling to others. With the help of the mediator, the child can reveal their interest in life and present it to their family, friends and society in proper language and communication. In opposite, mediator also help the family, friend and society to express their interest. Existence of a mediator in this event can boost the result of reintegration of child prisoner to his/her community.

With his/her skills, a mediator can focus on improving the problem solving, communication, and thinking skills of inmates. As stated before, mediation process help child and others to find win-win solution for both. That solution is the commitment of both parties to live together and rebuild their relationship. The commitment itself establish from the success of mediator to bridge both interest. This result can complement all needed requirement to obtain remission and parole.

\section{E. CLOSING}

Preparing prisoners better for release and supporting them better after release are crucial to successful of transition back into community. There are varieties of ways in which government may help prisoner (child) reconnect with the community while managing any potential safety or security risks. The use of 
mediation is one of them. Mediation with the help of mediator help child and their family, friend and society to find the best way to repair their neglected relationship. Child Prisoner Mediation (CPM) boosts the successful of reintegration program for the child to transit back into community. The result of mediation is an agreement between children and other parties, family, friends and society, which can be used as one of requirement to gain remission and parole for the child. It is not only benefit the child because he/she can get reduction of sentence but also benefit the family, friends and society because the guarantee that the child has been restore. Lastly, it also decrease the chance of child turning into recidivism.

\section{F. ACKNOWLEDGEMENT}

We would like to thank everyone for his or her help in finishing this article (interviewees).

\section{BIBLIOGRAPHY:}

\section{Books:}

C. T. Griffiths, Y. Dandurand and D. Murdoch, 2007, The Social Reintegration of Offenders and Crime Prevention, Ottawa: Public Safety Canada, National Crime Prevention Centre.

Kristina Simion, 2016, Practitioner's Guide: Qualitative and Quantitative Approaches to Rule of Law Research, United States: INPROL.

M. Borzycki and T. Makkai, 2007 Prisoner Reintegration Post-release, Canberra: Australian Institute of Criminology, 2007.

United Nation Office on Drugs and Crime, 2012, Introductory Handbook on the Prevention of Recidivism and the Social Reintegration of Offenders, Criminal Justice Handbooks Series, Newyork: United Nation Press.

\section{Journals:}

David Smith, "Probation and Social Work", British Journal of Social Work, 35, 621- 637, 2005.

Laurel Kaufer, Douglas E. Noll, and Jessica Mayer, "Prisoner Facilitated Mediation: Bringing Peace to Prisons and Communities," Cardozo J. of Conflict Resolution, Newyork: Cardozo Law School, vol. 16, 2015. 
R. Ruddell and L. T. Winfree, "Setting aside criminal convictions in Canada: a successful approach to offender reintegration", The Prison Journal, vol. 86, No. 4, 2006.

Shawn M. Flower, "Re-Entry Mediation: Reducing Recidivism by Building Relationships", Justice Research and Statistic Association, Vol. 31, No. 4, December 2013.

\section{Internet Article:}

Janus Conflict Management Service, "Prisoner Re-entry Mediation Better than Cable Everytime", available at: http://boldmovestudio.com/janus/2012/03/09/ prisoner-re-entry-mediation-better-than-cable-everytime

http://mdmediation.org/cmm-initiatives/re-entry-mediation

http://www.goodreads.com/quotes/tag/child 